\title{
Halal cosmetics and behavior of Muslim women in Indonesia: the study of antecedents and consequences
}

\author{
Frideswidi Aufi ${ }^{1}$, Hendy Mustiko Aji ${ }^{*}$ \\ ${ }^{1}$ Department of Management, Faculty of Business and Economics, Universitas \\ Islam Indonesia, Yogyakarta, Indonesia \\ *Corresponding author: hm.aji@uii.ac.id
}

\begin{abstract}
Purpose: This study aims to analyze the antecedents and consequences of the attitudes of Muslim women towards purchase intention of halal cosmetics.

Methodology: This sample was taken by using the purposive sampling technique. In total, 232 Muslim women respondents are aware of halal-labeled cosmetics. Data is processed using Partial Least Square-Structural Equation Modeling (PLS-SEM) method with SmartPLS.

Findings: The results of this study indicate that religiosity has a positive and significant influence on attitudes towards halal cosmetics, knowledge has a positive and significant influence on attitudes towards halal cosmetics, subjective norms have a positive and significant influence on attitudes towards halal cosmetics, and attitudes towards halal cosmetics has a positive and significant influence on purchase intention of halal cosmetics.
\end{abstract}

Originality: Due to the inconsistent findings from past studies, the results of this study are expected to contribute to the literature in evaluating the behavioral intentions of Muslim women in Indonesia towards halal cosmetics. Cosmetics brand manufacturers can also use the results of this study for the halal labeling process of their products.

Keywords: religiosity, halal knowledge, subjective norms, attitude towards halal cosmetics, purchase intention.

Cite this article:

Aufi, F., \& Aji, H.M (2021). Halal Cosmetics and Behavior of Muslim Women in Indonesia: The Study of Antecedents and Consequences. Asian Journal of Islamic Management, 3 (1), 11-22. https://doi.org/10.1108/AJIM.vol3.iss1.art2
Article history

Received, 19 January 2021 Revised 1, 13 May 2021 Revised 2, 28 May 2021 Accepted, 31 May 2021

\section{Introduction}

For a woman, cosmetics represent a symbol of beauty. Cosmetics seem to be an immediate need for certain females, along with the times. Women not only use makeup to enhance the beauty of their faces but also to increase self-confidence. The Ministry of Industry of the Republic of Indonesia in 2018 stated that Indonesia is fertile land for the cosmetics industry with a population of around 250 million, making Indonesia a promising market for cosmetics companies. The existence of various cosmetics products on the market influences purchasing decisions and makes consumers more selective in choosing cosmetic brands. Consumers make many considerations before deciding to buy a product, such as seeing the label on the product packaging.

According to Thomson Reuters' report (2014), the amount of consumption of the world's Muslim population reached $17.4 \%$ of total world consumption. Indonesia takes the first position in the world's Muslim consumption because it has the largest Muslim population. For Muslims, consuming halal products is an obligation. Muslim women must be extra careful in choosing cosmetics and ensure that their cosmetics comply with sharia law by being halal. Yuswohady (2015) states that producers are busy embedding halal labels along with increasing awareness of the benefits of halal from Muslim consumers because it will also affect consumer purchase intentions of halal 
products. In choosing and using halal cosmetic products, consumers must have the intention to buy these cosmetic products. According to Ajzen (1991), behavioral intention is a person's tendency to choose to do or not do a job. To predict attitudes accurately, marketers must know consumer relationship interests because, according to Peter \& Olson (2000), purchase intention is often the best way to predict future purchase behavior. In the consumer behavior model, purchase intention is formed from beliefs about a product or brand and its attributes, followed by a shift in attitudes towards purchasing action and is influenced by internal and external factors. Thus, purchase intention is influenced by consumer attitudes towards halal cosmetic products.

Consumer attitudes are only based on belief and knowledge about certain goods or commodities. It results from gathering information that affects individual goals to behave in a certain attitude (Putri et al., 2019). For example, consumers' awareness of halal cosmetics has led to the trend of hijrah, halal market, and halal cosmetics among Indonesian people. Therefore, the manufacturer must be able to meet the demand from consumers to buy halal products. In this case, it can be said that attitudes towards halal cosmetic products are influenced by religiosity, halal knowledge, and subjective norms as a function of belief that determines the thinking of individual consumers.

Religiosity is a factor influencing consumer attitudes towards halal cosmetic products. Religiosity is the extent to which an individual commits to his religion and to whom that religion is reflected in the attitudes and behavior of the individual (Briliana \& Mursito, 2017). Religion is one of the factors that influence the lifestyle of consumers, which in turn will also influence decision-making behavior. The influence of religion on various aspects of human life has been investigated by many researchers in the social sciences (Lada \& Amin, 2009; Ireland \& Rajabzadeh, 2011; Mukhtar \& Butt, 2012; Teng \& Wan, 2013; Hassan \& Harun, 2016).

Apart from religiosity, attitudes towards halal cosmetic products are also influenced by halal knowledge. It refers to the expertise and skills acquired by a person or group of people through a theoretical or practical understanding of a subject (Rahman et al., 2015). Rao \& Monroe (1988) stated that product knowledge can influence how consumers access products. Furthermore, consumer knowledge is a fundamental concept for understanding consumer decisions in shaping and changing attitudes and adopting new technology (Oh \& Abraham, 2016). Thus, the knowledge possessed by consumers about things that are forbidden and permissible in Islamic law will affect attitudes towards halal cosmetic products.

Not only do religiosity and halal knowledge influence attitudes towards halal cosmetic products, but also subjective norms. Lada \& Amin (2009) stated that subjective norm is a function of beliefs that determine individuals' acceptance of certain behaviors by a group. Consumers can make purchases because they are influenced by the environment, which is often called subjective norms. Subjective norms determine how a person acts and behaves. Mukhtar \& Butt (2012) revealed that subjective norms and intrapersonal religiosity positively affect attitudes towards halal products.

Halal cosmetics are starting to develop rapidly in Indonesia, and a growing number of researchers have conducted studies related to the attitudes of Muslim women towards purchasing intention of halal cosmetic products. Many studies have produced positive relationships between these variables, but some studies showed negative results. For example, Aji (2017) found that Islamic religiosity does not affect attitudes towards halal labeled products and intention to buy products labeled halal. In addition, Rahman et al. (2015) also found that knowledge did not significantly influence attitudes towards halal cosmetics. Likewise, the results of Nora's (2016) study found that inaction is an intermediary for the influence of religiosity on purchase intention.

Thus, empirically, the findings of previous studies related to the relationship between attitudes towards halal cosmetics and purchase intention towards halal cosmetics are still inconsistent. This becomes a problem and a research gap to be closed, so it is urgent why this research needs to be done. In general, this research model replicated Briliana \& Mursito's (2017) by changing the context to halal-labeled cosmetics.

The formulation of the problem in this study is as follows:

1. Does religiosity have a positive impact on attitudes towards halal cosmetic products? 
2. Does halal knowledge have a positive impact on attitudes towards halal cosmetic products?

3. Do subjective norms have a positive impact on attitudes towards halal cosmetic products?

4. Does the attitude towards halal cosmetic products have a positive impact on purchase intention?

\section{Literature Review and Hypotheses Development}

This study replicates the research model of Briliana \& Mursito (2017). Their research examines several variables such as knowledge, five dimensions of religiosity, subjective norms, attitudes towards halal cosmetics, and purchase intention with a sample of Muslim women in Jakarta. This study modifies the five-dimensional variable of religiosity into intrinsic and extrinsic religiosity variables in the context of Muslim women in Indonesia. This research model was also developed based on empirical studies on previous studies that raised the relationship between the four variables: knowledge, religiosity, attitudes, and purchase intention (Rahman et al., 2015; Aji, 2017; Nora, 2016; and Briliana \& Mursito, 2017). The results of their research in more detail can be seen in Table 1.

Table 1. Past studies on halal cosmetics

\begin{tabular}{|c|c|c|c|c|}
\hline Author & Research Title & $\begin{array}{l}\text { Research } \\
\text { Samples }\end{array}$ & Variables & Research Result \\
\hline $\begin{array}{l}\text { Rahman et al } \\
\text { (2015) }\end{array}$ & $\begin{array}{l}\text { Consumers and Halal } \\
\text { cosmetic products: } \\
\text { knowledge, religiosity, } \\
\text { attitude and intention }\end{array}$ & $\begin{array}{l}\text { Non-probability } \\
\text { convenience } \\
\text { sampling. }\end{array}$ & $\begin{array}{l}\text { Knowledge, } \\
\text { Religiosity, Attitude, } \\
\text { and Intention }\end{array}$ & $\begin{array}{l}\text { - Knowledge does not have a significant effect } \\
\text { on attitudes } \\
\text { - Religiosity affects attitudes } \\
\text { - Attitude affects purchase intention. }\end{array}$ \\
\hline $\begin{array}{l}\text { Aji, H.M } \\
\text { (2017) }\end{array}$ & $\begin{array}{l}\text { Examining the } \\
\text { moderating role of } \\
\text { bigh-versus-low } \\
\text { scepticism toward } \\
\text { Halal labels: findings } \\
\text { from Indonesia }\end{array}$ & $\begin{array}{l}186 \text { respondents } \\
\text { with the criteria of } \\
\text { Muslims who } \\
\text { known or seen } \\
\text { halal-labeled } \\
\text { products }\end{array}$ & $\begin{array}{l}\text { Islamic Religiosity, } \\
\text { Knowledge about } \\
\text { Halal, Halal } \\
\text { skepticism, Consumer } \\
\text { attitude, Halal } \\
\text { purchase intention }\end{array}$ & $\begin{array}{l}\text { Knowledge about Halal processes and } \\
\text { procedures is significantly affected by Islamic } \\
\text { religiosity } \\
\text { - Knowledge about Halal processes and } \\
\text { procedures does not significantly affect attitude } \\
\text { toward Halal labeled products } \\
\text { - Islamic religiosity does not affect attitudes } \\
\text { towards halal-labeled products and intention to } \\
\text { buy halal-labeled products } \\
\text { - The influence of Islamic religiosity on intention } \\
\text { to buy halal-labeled products is negatively } \\
\text { moderated by consumer skepticism about halal }\end{array}$ \\
\hline $\begin{array}{l}\text { Nora, L. } \\
\text { (2016) }\end{array}$ & $\begin{array}{l}\text { The Role of } \\
\text { Religiosity, Lifestyle, } \\
\text { Attitude as } \\
\text { Determinant Purchase } \\
\text { Intention }\end{array}$ & $\begin{array}{l}289 \text { respondents at } \\
\text { the University of } \\
\text { Muhamadiayah } \\
\text { Jakarta Islamic State } \\
\text { University Syarif } \\
\text { Hidayatullah, } \\
\text { wearing hijab as a } \\
\text { criterion of } \\
\text { respondents. }\end{array}$ & $\begin{array}{l}\text { Religiosity, Lifestyle, } \\
\text { Attitude, Purchase } \\
\text { Intention }\end{array}$ & $\begin{array}{l}\text { - Religiosity has a positive and significant effect } \\
\text { on purchase intention } \\
\text { - Lifestyle does not act as a mediator of the } \\
\text { religiosity effect on purchase intentions } \\
\text { - Attitude does not act as an intermediary for the } \\
\text { influence of religiosity on the intention of } \\
\text { purchase } \\
\text { - Attitude as mediator lifestyle influence on } \\
\text { purchase intentions }\end{array}$ \\
\hline $\begin{array}{l}\text { Briliana \& } \\
\text { Mursito } \\
\text { (2017) }\end{array}$ & $\begin{array}{l}\text { Exploring antecedents } \\
\text { and consequences of } \\
\text { Indonesian Muslim } \\
\text { youths' attitude } \\
\text { towards halal cosmetic } \\
\text { products: A case study } \\
\text { in Jakarta }\end{array}$ & $\begin{array}{l}400 \text { respondents in } \\
\text { Jakarta with the } \\
\text { criteria: Muslim } \\
\text { women, members } \\
\text { of Muslim societies, } \\
\text { routinely use } \\
\text { cosmetics but have } \\
\text { never bought or } \\
\text { used Wardah } \\
\text { cosmetics. }\end{array}$ & $\begin{array}{l}\text { Knowledge, } \\
\text { Religiosity } \\
\text { (Ideological, } \\
\text { Ritualistic, Intellectual, } \\
\text { Consequential, } \\
\text { Experimental, } \\
\text { Subjective norm, } \\
\text { attitude towards halal } \\
\text { cosmetic products, } \\
\text { purchase intention }\end{array}$ & $\begin{array}{l}\text { - Knowledge is significantly related to attitude } \\
\text { towards halal cosmetic products } \\
\text { - Ideological found to be a predictor of attitudes } \\
\text { towards halal cosmetic products } \\
\text { - Ritualistic has a negative influence on attitude } \\
\text { towards halal cosmetic products } \\
\text { - Intellectual has a positive and significant } \\
\text { influence on attitude toward halal cosmetic } \\
\text { products } \\
\text { - Consequential has a positive and significant } \\
\text { influence on attitude toward halal cosmetic } \\
\text { - Exoducts } \\
\text { influence on attitude toward halal cosmetic } \\
\text { - Suboducts } \\
\text { - Attitude towards halal cosmetic products } \\
\text { positidive and significant influence on purchase } \\
\text { intention. }\end{array}$ \\
\hline
\end{tabular}




\section{Religiosity and Attitude toward Halal Cosmetics}

According to Souiden \& Rani (2015), the level of religiosity is a determinant of the attitudes and behavior of Muslim consumers. Religiosity significantly affects a person's intention in choosing halal products (Balques et al., 2017; Mukhtar \& Butt, 2012; Tabassi, 2012). Consumers with a high level of religiosity are very concerned about the halal label used to identify halal cosmetic products. This statement is supported by research by Adriani et al. (2020), which states that consumers who have high religiosity will be more concerned and aware of the importance of halal cosmetics. However, Aji (2017) found that religiosity does not influence attitudes towards halal-labeled products and intention to buy halal-labeled products. In this study, the researcher argues that high religiosity can affect consumer attitudes towards halal cosmetics. The more religious consumers are, the more likely they are to choose halal cosmetics. Thus, based on this explanation, the formulated hypothesis is as follows:

H1: Religiosity has a positive impact on attitudes towards halal cosmetic products

\section{Halal Knowledge and Attitudes toward Halal Cosmetics}

Knowledge influences intention through attitude; hence, increased knowledge is likely to influence intention (Bang et al., 2000; Aji et al., 2020). According to Adriani et al. (2020), knowledge of halal products positively and significantly affects consumer attitudes and purchase intentions. Larasati et al. (2018) supported this statement, who found that knowledge positively influences consumer attitudes towards halal cosmetic products. However, Rahman et al. (2015) revealed that knowledge did not significantly influence attitudes towards halal cosmetic products. In this study, researchers argue that when someone has good knowledge of halal cosmetic products, it will affect attitudes towards halal cosmetic products. When consumers understand the context of halal and haram in cosmetic products, Muslim consumers will make halal cosmetics their choice. Based on this explanation, the hypotheses that can be formulated are as follows:

H2: Halal knowledge has a positive impact on attitudes towards halal cosmetic products

\section{Subjective Norms and Attitudes toward Halal Cosmetics}

Mukhtar \& Butt (2012) revealed that subjective norms, attitudes towards halal products, and intrapersonal religiosity positively affect consumer attitudes towards halal products. Their findings align with Endah's (2014) study, which shows that subjective norms greatly influence consumer attitudes about halal cosmetics. Briliana \& Mursito (2017) also supported this statement, which found that subjective norms are significantly related to attitudes towards halal cosmetic products. A person will consider several things when making decisions, including references from his friends or family. Therefore, researchers argue that in this study, the individual decision to purchase halal cosmetic products will be influenced by family, friends, or important people in their lives. Based on this explanation, the hypotheses that can be formulated are as follows:

H3: Subjective norms have a positive impact on attitudes towards halal cosmetic products

\section{Attitude toward Halal Cosmetics and Purchase Intention}

Based on the Theory of Planned Behavior (TPB), an individual's behavioral intention is influenced by attitudes, subjective norms, and perceived behavior control. Previous research has found that the more positive customer attitudes, the more positive their purchase intention for halal cosmetics (Balque et al., 2017). Lada \& Amin (2009) found a positive relationship between attitude and intention to choose halal products. Alam \& Sayuti (2011) reinforced this statement, who found a significant and positive relationship between attitude and intention to buy halal products. Rahman et al. (2015) and Divianjella et al. (2021) also found that attitudes towards halal cosmetics affect purchase intentions. In the context of this research, consumers' attitudes towards a product will encourage them to purchase halal-labeled cosmetics. Therefore, the authors assumed that when 
someone feels that halal cosmetics are good, they will have an intention to buy them. Based on this explanation, the hypotheses that can be formulated are as follows:

H4: Attitude towards halal cosmetic products has a positive impact on purchase intention

\section{Methodology}

\section{Data Collection and Sampling Techniques}

In general, this study used a quantitative approach. The object of this research is halal cosmetics. It is defined as cosmetics that are made from ingredients that do not contain haram elements and have a halal label issued by the Indonesian Ulema Council (MUI), namely Wardah, Mazaya, Safi, Zoya, Purbasari, and Sariayu. The research location was not limited to Yogyakarta because the questionnaires were distributed online via Microsoft Form, then distributed to social media. The questionnaire was distributed to several social media such as Instagram, Twitter, and TikTok. The distribution of questionnaires on Instagram was carried out by embedding the questionnaire link in the bio and through direct messages. On Twitter, the questionnaire was distributed through community accounts around schools and lectures. Then on TikTok, the questionnaire was distributed with live features carried out by the author. The authors also distributed the questionnaire via LINE and WhatsApp.

The sample was selected using a purposive sampling method, with the criteria of Muslim women who knew halal labeled cosmetics. The sample size in this study uses the Roscoe formula (1975), which can be calculated with minimum sample size: 5 x number of observations (items) and maximum sample size: $10 \mathrm{x}$ number of observations (items). In this study, there were 25 observations (items), so that the minimum size was $5 \times 25=125$ and a maximum of $10 \times 25=250$.

\section{Operational Definition and Variable Measurement}

Johnson et al. (2001) define religiosity as an individual's commitment to religion and acknowledge its teachings, such as individual attitudes and behavior. Islamic religiosity is defined by El-Menouar (2014) as Muslim faith in the pillars of Islam and the pillars of faith, as well as behavior in practicing religious teachings. In this study, religiosity is operationally defined as how far a Muslim woman is committed to her religion in carrying out the pillars of Islam and her fear of sin. The higher the religiosity of Muslim women, the more careful they will determine the cosmetics to be used. This study uses measurement items taken from the research of Alam et al. (2012), including "I always pray five times a day", "I always fast fully in the month of Ramadan", "I always take the time to read the Koran", "If my assets are sufficient, I will pay zakat "," I try to comply with Islamic teachings in all aspects of life "," I always try to avoid small and big sins".

Maichum, Parichatnon, \& Peng (2017) said that knowledge is essential for consumers in making product purchase decisions, especially halal products. Operationally, halal knowledge in this study represents how well Muslim women understand haram and halal in halal cosmetics. This study uses measurement items taken from the research of Abd Rahman et al. (2015), namely "I understand halal and haram related to cosmetics", "I have sufficient knowledge of halal and haram cosmetics", "I have sufficient knowledge to distinguishes between halal and haram cosmetics "," I know the issues related to the probibited ingredients in cosmetics "," I understand the rules of halal certification for cosmetic products ".

Theoretically, Lada \& Amin (2009) explain that subjective norms are a function of beliefs that determine a person's thinking about accepting specific behavior by a related group, for example consuming halal products. As for operationally, this study defines subjective norms with the influence of friends and family in making decisions to choose halal cosmetic products. This study adapted a 5-item measurement from Alam et al. (2012) including, "People who are important to me support me to use halal cosmetics", "Most of my friends who have used halal cosmetics agree that halal cosmetics is better", "In choosing cosmetics, I follow my friends' choices", etcetera. 
In this study, attitudes are operationally defined by the behavior of Muslim women towards halal cosmetics. A positive attitude of Muslim women towards halal cosmetics will be formed when they prefer cosmetics labeled halal, but if not, it will cause a negative attitude. This study uses measurement items taken from the research of Abd Rahman et al. (2015), namely "I like cosmetics labeled halal", "I have a positive impression of cosmetics with a halal label", "I feel happy when using cosmetics with a halal label", "Using halal cosmetics is my own choice".

Furthermore, purchase intention in this study is operationally defined by the desire of Muslim women to buy and use halal cosmetics in the future. This study uses measurement items taken from the research of Alam et al. (2012), namely "I intend to choose halal cosmetics", "I will most likely buy halal cosmetics", "I hope to buy halal cosmetics in the future", "I predict that I will buy halal cosmetics in the future", "I plan to buy halal cosmetics".

\section{Results}

\section{Respondent Demographic Characteristics}

The questionnaire in this study was created using Microsoft Form. Overall, there were 318 respondents. Of the total 318 respondents obtained, 232 were usable following research objectives that focused on Muslim women. The first classification based on gender was 232 respondents $(100 \%)$. In terms of marital status, five respondents were married $(2.16 \%)$, while 227 respondents were unmarried (97.84\%). Based on religion, all respondents are Muslim, as many as 232 respondents $(100 \%)$. It was found that 92 respondents were aged $<20$ years $(39.66 \%), 139$ respondents were 20-30 years old (59.91\%), the rest was only one respondent aged 31-40 years $(0.43 \%)$. In terms of educational background, the respondents were dominated by a senior high school graduate $72.41 \%, 41$ respondents were a bachelor's degree (17.67\%), and 17 respondents were junior high school graduates $(7.33 \%)$. Lastly, six respondents were associated with degrees $(2.59 \%)$.

In terms of job, students were the majority of respondents $(\mathrm{N}=209$ respondents, $90.09 \%)$, nine respondents $(3.88 \%)$ were employees, seven respondents $(3.02 \%)$ were entrepreneurs, and five respondents were unemployed $(2.15 \%)$. The remaining two respondents $(0.87 \%)$ were civil servants. This study was dominated by respondents from Java Island $(\mathrm{N}=158,68.10 \%)$, from Sumatra Island, 26 respondents (11.21\%), from Kalimantan Island, as many as 12 respondents (5.17\%), 15 respondents from Sulawesi Island (6.47\%), Papua as many as 17 respondents $(7.33 \%)$ and the remaining three respondents came from the Riau Islands $(1.29 \%)$.

The halal cosmetic products known by the respondents were classified into six products, namely Wardah, Safi, Mazaya, Zoya Cosmetics, Sari Ayu (Martha Tilaar), and Purbasari. Based on this classification, 203 respondents knew Wardah (87.50\%), 27 respondents knew Safi $(11.64 \%)$, one respondent knew Sari Ayu $(0.43 \%)$, Purbasari is known by one respondent $(0.43 \%)$, and no respondents knew Mazaya and Zoya Cosmetics. Respondent profile data can be seen in Table 2.

\section{Measurement Model Test: Validity and Reliability}

Validity testing is divided into two, namely convergent validity and discriminant validity. The criteria for good convergent validity are AVE> 0.5 (Hair et al., 2017). As for the discriminant validity, the thing that must be considered is that each variable's square roots AVE value is greater than the correlation value of other variables. As shown in Table 4, the square roots AVE value in the diagonal column is greater than the score below. Therefore, it shows that all data are free from discriminant validity problems. A reliability test is done by considering the value of composite reliability (CR). The CR value is considered good if it is more than 0.70 (Hair et al., 2017). As presented in Table 3 , the CR value of all variables is more than 0.70 . Thus, it can be concluded that the measurement items in this study are reliable. 


\section{Inner Model Testing: Structural Model}

$\mathrm{R}^{2}$ is used to see how much the antecedent variable affects the dependent variable. For example, figure 1 explains that the R2 of the purchase intention variable for halal cosmetics is $64 \%$, so it can be interpreted that purchase intention can be explained by $64 \%$ by the antecedent variable; other variables explain $36 \%$. Then, the variable attitude towards halal cosmetics in this research model is explained by $51 \%$ by religiosity, halal knowledge, and subjective norms. Another $49 \%$ is influenced by other variables that are not described in this study.

Tabel 2. Profile of Respondents

\begin{tabular}{|c|c|c|}
\hline Category & $\mathbf{N}$ & $\%$ \\
\hline \multicolumn{3}{|l|}{ Status } \\
\hline Married & 5 & $2.16 \%$ \\
\hline Single & 227 & $97.84 \%$ \\
\hline \multicolumn{3}{|l|}{ Age } \\
\hline$<20$ & 92 & $39.66 \%$ \\
\hline $21-30$ & 139 & $59.91 \%$ \\
\hline $31-40$ & 1 & $0.43 \%$ \\
\hline $41-50$ & 0 & $0 \%$ \\
\hline$>50$ & 0 & $0 \%$ \\
\hline \multicolumn{3}{|l|}{ Occupation } \\
\hline Student & 209 & $90.09 \%$ \\
\hline Employee & 9 & $3.88 \%$ \\
\hline Civil servants & 2 & $0.86 \%$ \\
\hline Entrepreneur & 7 & $3.02 \%$ \\
\hline Housewife & 0 & $0 \%$ \\
\hline Unemployed & 5 & $2.15 \%$ \\
\hline \multicolumn{3}{|l|}{ Background of education } \\
\hline Out-of-school & 0 & 0 \\
\hline Elementary school & 0 & 0 \\
\hline Junior high school & 17 & $7.33 \%$ \\
\hline Senior High school & 168 & $72.41 \%$ \\
\hline Associate's degree & 6 & $2.59 \%$ \\
\hline Bachelor's degree & 41 & $17.67 \%$ \\
\hline Master's degree & 0 & $0 \%$ \\
\hline Doctoral degree & 0 & 0 \\
\hline \multicolumn{3}{|l|}{ Origin } \\
\hline Java & 158 & $68.10 \%$ \\
\hline Kalimantan & 12 & $5.17 \%$ \\
\hline Sumatera & 26 & $11.21 \%$ \\
\hline Sulawesi & 15 & $6.47 \%$ \\
\hline Bali & 1 & $0.43 \%$ \\
\hline Papua & 17 & $7.33 \%$ \\
\hline Riau Island & 3 & $1.29 \%$ \\
\hline Maluku Island & 0 & $0 \%$ \\
\hline \multicolumn{3}{|c|}{ Halal cosmetic that you know } \\
\hline Wardah & 203 & $87.50 \%$ \\
\hline Safi & 27 & $11.64 \%$ \\
\hline Mazava & 0 & $0 \%$ \\
\hline Zoya Cosmetics & 0 & $0 \%$ \\
\hline Sari Ayu (Martha Tilaar) & 1 & $0.43 \%$ \\
\hline Purbasari & 1 & $0.43 \%$ \\
\hline
\end{tabular}


Table 3. Outer model testing

\begin{tabular}{|c|c|c|c|c|}
\hline Items & Est & AVE & $\mathbf{C R}$ & Means \\
\hline Factor 1: Religiosity & & 0.585 & 0.849 & \\
\hline I regularly offer prayer five times a day & 0.761 & & & 4.130 \\
\hline I always take the time to read the Qur'an & 0.733 & & & 3.820 \\
\hline I try to follow Islamic conjunctions in all matters of my life & 0.806 & & & 4.280 \\
\hline I always try to avoid minor and major sin & 0.759 & & & 4.040 \\
\hline Factor 2: Halal Knowledge & & 0.646 & 0.901 & \\
\hline I understand Islamic laws of Halal and Haram for cosmetics & 0.787 & & & 3.590 \\
\hline I have sufficient knowledge of Halal and Haram for cosmetics & 0.800 & & & 3.340 \\
\hline $\begin{array}{l}\text { I have enough knowledge to differentiate between halal and haram } \\
\text { cosmetics }\end{array}$ & 0.844 & & & 3.360 \\
\hline $\begin{array}{l}\text { I know about the current issues regarding cosmetics ingredients } \\
\text { such as pork gelatin }\end{array}$ & 0.825 & & & 3.470 \\
\hline I understand the rules of halal certification for cosmetic products & 0.758 & & & 3.470 \\
\hline Factor 3: Subjective norms & & 0.660 & 0.853 & \\
\hline $\begin{array}{l}\text { Most people who are important to me support me using halal } \\
\text { cosmetics }\end{array}$ & 0.862 & & & 3.91 \\
\hline $\begin{array}{l}\text { Most of my friends who have used halal cosmetics agreed that } \\
\text { halal cosmetics are better }\end{array}$ & 0.849 & & & 3.73 \\
\hline $\begin{array}{l}\text { People whom I listen to could influence me to use halal } \\
\text { cosmetics }\end{array}$ & 0.717 & & & 3.63 \\
\hline Factor 4: Attitude towards halal cosmetics & & 0.743 & 0.920 & \\
\hline I like halal-labeled cosmetics & 0.888 & & & 4.22 \\
\hline I have a positive impression of halal-labeled cosmetics & 0.845 & & & 4.21 \\
\hline I feel happy when I use halal-labeled cosmetics & 0.867 & & & 4.10 \\
\hline Using halal-labeled cosmetics is my own choice & 0.849 & & & 4.14 \\
\hline Factor 5: Purchase intention & & 0.784 & 0.948 & \\
\hline I intend to choose halal cosmetics & 0.880 & & & 4.16 \\
\hline I will likely buy halal cosmetics & 0.890 & & & 4.09 \\
\hline I expect to buy halal cosmetics in future & 0.880 & & & 4.27 \\
\hline I predict I will buy halal cosmetics & 0.873 & & & 4.24 \\
\hline I plan to buy halal cosmetics & 0.903 & & & 4.18 \\
\hline
\end{tabular}

Table 4. Discriminant validity

\begin{tabular}{lccccc}
\hline & $\begin{array}{c}\text { Purchase } \\
\text { Intention }\end{array}$ & $\begin{array}{c}\text { Subjective } \\
\text { Norms }\end{array}$ & $\begin{array}{c}\text { Halal } \\
\text { Knowledge }\end{array}$ & Religiosity & $\begin{array}{c}\text { Attitude towards } \\
\text { Halal Cosmetics }\end{array}$ \\
\hline Purchase Intention & $\mathbf{0 . 8 8 5}$ & & & & \\
Subjective norms & 0.561 & $\mathbf{0 . 8 1 2}$ & & & \\
Halal knowledge & 0.415 & 0.453 & $\mathbf{0 . 8 0 4}$ & & \\
Religiosity & 0.473 & 0.367 & 0.375 & $\mathbf{0 . 7 6 5}$ & \\
Attitude towards halal cosmetics & 0.799 & 0.648 & 0.483 & 0.476 & $\mathbf{0 . 8 6 2}$ \\
\hline
\end{tabular}

The predictive relevance is used to analyze how relevant variables predict a model by looking at the value of Q2. Q2 testing was conducted to determine the goodness of fit in this study. The higher the Q2 value, the better the data. Both variables in this study can be suitable and have predictive relevance for value $>0$. In Figure 1, we can see that intention to purchase halal cosmetics has a Q2 value of $0.50(50 \%)$ while attitude towards halal cosmetics is $0.37(37 \%)$. It shows that both variables have predictive relevance. Purchase intention was predicted by $50 \%$ by the attitude variable towards halal cosmetics. Religiosity, knowledge, and subjective norms predicted attitude towards halal cosmetics by $37 \%$. Thus, it can be concluded that the model used in this study has good predictive relevance. 


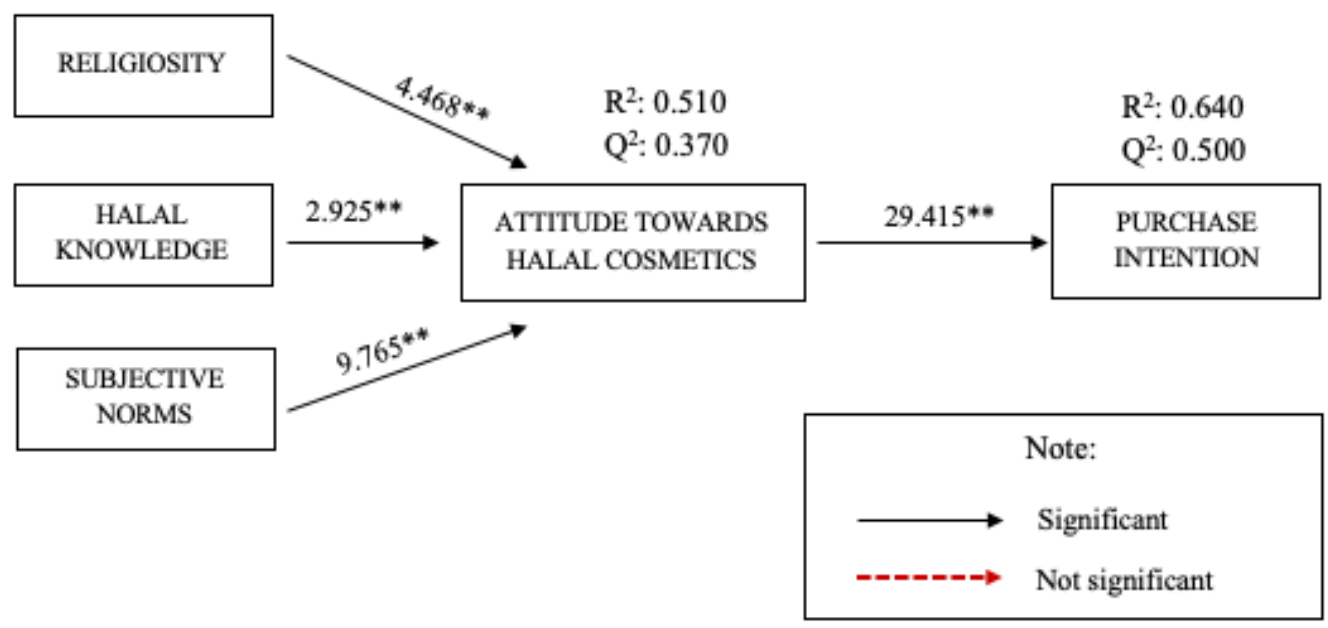

Figure 1. Structural Test Results

Table 5. Hypotheses Testing

\begin{tabular}{lcccc}
\hline & $\begin{array}{c}\text { Original Sample } \\
(\mathbf{O})\end{array}$ & $\begin{array}{c}\text { T Statistics } \\
(\mathbf{O} / \text { STDEV) }\end{array}$ & P Values & Conclusion \\
\hline RG $\rightarrow$ ATH & 0.231 & 4.468 & 0.000 & H1 supported \\
KN $\rightarrow$ ATH & 0.177 & 2.925 & 0.004 & H2 supported \\
SN $\rightarrow$ ATH & 0.484 & 9.765 & 0.000 & H3 supported \\
ATH $\rightarrow$ PI & 0.800 & 29.415 & 0.000 & H4 supported \\
\hline
\end{tabular}

Notes: $\mathrm{RG}=$ Religiosity; $\mathrm{KN}=$ Halal Knowledge; $\mathrm{SN}=$ Subjective Norms; ATH = Attitudes towards

Halal Cosmetics; PI = Purchase Intention

Figure 1 shows the path coefficient test results for each variable. Religiosity has a positive and significant effect on attitudes towards halal cosmetics ( $\mathrm{t}$-statistic $=4,468 ; \mathrm{p}$-value $0.000<0.05$ ). Halal knowledge has a positive and significant effect on attitudes towards halal cosmetics (t-statistic $=2.925 ; \mathrm{p}$-value $0.004<0.05)$. Subjective norms has a positive and significant effect on attitudes towards halal cosmetics (t-statistic $=9.765 ; \mathrm{p}$-value $0.000<0.05$ ), and attitudes towards halal cosmetics have a positive and significant effect on purchase intention ( $\mathrm{t}$-statistics $=29.415$; $\mathrm{p}$-value $=0.000)$. These results indicate that all hypotheses are supported and have a significant relationship. More detailed information can also be seen in Table 5.

\section{Discussion}

In general, the results of statistical testing show that all the hypotheses in this study are supported. The results of this study are supported by several previous studies, such as research conducted by Larasati et al. (2018), which concluded that the level of religiosity that consumers have has a positive influence on their attitudes towards halal cosmetic products. In addition, similar research results were also found in Rahman et al. (2015), which showed the influence of religiosity on consumer attitudes towards halal cosmetics. The results obtained in this study indicate relevance to the market conditions for cosmetics labeled halal in Indonesia. Many consumers have a good attitude and choose halal cosmetics, so that cosmetics manufacturers start competing to embed halal labels on their products to meet the increasing demand of Muslim consumers. If it is related to this research, there is a possibility that a person's high level of religiosity affects their behavior towards halal cosmetics as their choice. The higher the consumer religiosity, the more influential it will be on consumer attitudes towards halal cosmetics.

In addition, Clarita \& Setiowati (2020), in their research, found a positive and significant relationship between halal knowledge and attitudes towards halal cosmetics. Aji (2017), in his research, also found that attitudes towards halal-labeled products are influenced by knowledge of 
halal processes and procedures if consumers have low skepticism about the halal label. Tsakiridou (2012) found that a good level of education influences knowledge and primary considerations in buying products. Of course, respondents who are dominated by students get knowledge of religion at school and campus so that they have obtained a basic knowledge of halal and haram. Such religious knowledge is implemented in everyday life, including when buying a product that first sees its contents, whether it is safe and lawful or vice versa. This explanation indicates that Muslim women in Indonesia have sufficient knowledge about halal cosmetics and form a good attitude towards halal cosmetics.

This study supports the research conducted by Mukhtar \& Butt (2012), which revealed that subjective norms positively influence attitudes towards halal products. This study also supports Endah (2014). The respondents of this study are dominated by those aged between 20-30 years old. During that age category, people are actively seeking information before making a purchase decision. They can get information search from friends, product reviews on social media, and their families. The amount of information and references obtained raises his attitude towards a product, in this case, related to halal cosmetics, so this research proves that subjective norms have a significant positive effect on consumer attitudes towards halal cosmetics. It means that before purchasing halal cosmetics, a person will depend on the individual or group he believes.

This finding also supports Rahman et al. (2015), who states that attitudes towards halal cosmetics have a significant positive effect on purchase intention. The better consumer attitudes towards halal cosmetics, the better the intention to purchase halal cosmetics. In connection with the respondents' jobs, most of them are students who are more educated and have broader insight. They can search for information related to products purchased from various sources, especially from social media. It can form a good attitude towards a product and then generate purchase intentions.

\section{Conclusion}

In conclusion, all hypotheses are supported. However, based on the results of R2, other antecedent variables can explain the dependent variable. For that, it is suggested for further research to consider other factors that are the influence of the dependent variable. The findings in this study also can be used by cosmetics brand manufacturers as one of the bases for making halal labeling on their products in the future.

\section{References}

Adriani, Lisa \& Ma'ruf. (2020). Analisis Perilaku Islami Terhadap Niat Beli Kosmetik Halal Melalui Sikap Konsumen. Journal of Management and Business Review, 17, 108-124.

Aji, H. M. (2017). Examining the moderating role of high-versus-low scepticism toward Halal labels: findings from Indonesia. International Journal of Islamic Marketing and Branding, 2(4), 278-303. https://doi.org/10.1504/IJIMB.2017.088999

Ajzen, I. (1991). The theory of planned behavior. Organizational behavior and buman decision processes, $50(2), 179-211$.

Aji, H. M., Berakon, I., \& Riza, A. F. (2020). The effects of subjective norm and knowledge about riba on intention to use e-money in Indonesia. Journal of Islamic Marketing. https://doi.org/10.1108/JIMA-10-2019-0203

Alam, S. S. and Sayuti, N. M. (2011). Applying the Theory of Planned Behavior (TPB) in halal food purchasing. International Journal of Commerce and Management, 21, 8-20.

Bang, H. K., Ellinger, A. E., Hadjimarcou, J., \& Traichal, P. A. (2000). Consumer concern, knowledge, belief, and attitude toward renewable energy: An application of the reasoned action theory. Psychology and Marketing, 17(6), 449-468. 
Briliana, V., \& Mursito, N. (2017). Exploring antecedents and consequences of Indonesian Muslim youths' attitude towards halal cosmetic products: A case study in Jakarta. Asia Pacific Management Review, 22(4), 176-184.

Clarita, N. M. A., \& Setiowati, R. (2020). Factors impacting customer attitude toward buying halal cosmetics in Jabodetabek. The Winners, 21(1), 7-13. https://doi.org/10.21512/tw.v21i1.5873

Divianjella, M., Muslichah, I, \& Ariff, Z.H.A (2020). Do religiosity and knowledge affect the attitude and intention to use halal cosmetic products? evidence from Indonesia, Asian Journal of Islamic Management, 2(2), 71-81. https://doi.org/10.1108/AJIM.vol2.iss2.art1

Endah, N. H. (2014). Perilaku Pembelian Kosmetik Berlabel Halal oleh Konsumen Indonesia. Jurnal Ekonomi dan Pembangunan, 22(1), 11-25. https://doi.org/10.14203/JEP.22.1.2014.2539

El-Menouar, Y. (2014). The five dimensions of Muslim religiosity. Results of an empirical study. MDA Methods, Data, Analyses, 8(1), 53-78. https://doi.org/10.12758/mda.2014.003

Hair Jr, J. F., Sarstedt, M., Ringle, C. M., \& Gudergan, S. P. (2017). Advanced issues in partial least squares structural equation modeling. SAGE publications.

Hassan, S. H., \& Harun, H. (2016). Factors influencing fashion consciousness in hijab fashion consumption among hijabistas. Journal of Islamic Marketing, 7(4), 476-494. https://doi.org/10.1108/JIMA-10-2014-0064

Ireland, J., \& Rajabzadeh, S. A. (2011). UAE consumer concerns about halal products. Journal of Islamic Marketing, 2 (3), 274-283. https://doi.org/10.1108/17590831111164796

Johnson, B. R, Jang, S. J, Larson, D.B, \& Li, S. De. (2001). Does Adolescent Religious Commitment Matter? A reexamination of the Effects of Religiosity on delinquency. Journal of Research in Crime and Delinquency, 38(1), 22-44. https://doi:10.1177/0022427801038001002

Lada, S., Tanakinjal, G. H., \& Amin, H. (2009). Predicting intention to choose halal products using theory of reasoned action. International Journal of Islamic and Middle Eastern Finance and Management, 2 (1), 66-76. https://doi.org/10.1108/17538390910946276

Larasati, A., Hati, S. R. H., \& Safira, A. (2018). Religiusitas dan Pengetahuan Terhadap Sikap dan Intensi Konsumen Muslim Untuk Membeli Produk Kosmetik Halal. Esensi: Jurnal Bisnis dan Manajemen, 8(2), 105 - 114. doi: 10.15408/ess.v8i2.7459.

Maichum, K., Parichatnon, S., \& Peng, K.-C. (2017). The Influence of Attitude, Knowledge and Quality on Purchase Intention towards Halal Food: A Case Study of Young Non-Muslim Consumers in Thailand. IRA-International Journal of Management \& Social Sciences (ISSN 24552267), 6(3), 354.

Mas'ud, M. H. (2012). Pengaruh Sikap, Norma-Norma Subyektif dan Kontrol Perilaku yang Dipersepsikan Nasabah Bank Terhadap Keinginan untuk Menggunakan Automatic Teller Machine (ATM) Bank BCA di Kota Malang. Jurnal Manajemen dan Akuntansi, 1(3), 13-28.

Mukhtar, A., \& Butt, M. M. (2012). Intention to choose Halal products: the role of religiosity. Journal of Islamic Marketing, 3(2), 108-120. https://doi.org/10.1108/17590831211232519

Nora, Liza \& Minarti, N. S. (2016). The Role of Religiosity, Lifestyle, Attitude as Determinant Purchase Intention. The 2nd International Multidisciplinary Conference 2016, (October 2016), 135148.

Oh, K. and Abraham, L. (2016). Effect of knowledge on decision making in the context of organic cotton clothing, International Journal of Consumer Studies, 40(1), 66-74. https://doi.org/10.1111/ijcs.12214 
Peter, J. P., \& Olson, J. C. (2000). Consumer behavior: Perilaku konsumen dan strategi pemasaran. Jakarta: Erlangga.

Putri, I. S., Daryanti, S., \& Ningtias, A. R. (2019). The influence of knowledge and religiosity with mediation of attitude toward the intention of repurchasing halal cosmetics. In 12th International Conference on Business and Management Research (ICBMR 2018). Atlantis Press.

Rahman, A. A., Asrarhaghighi, E., \& Rahman, S. A. (2015). Consumers and halal cosmetic products: Knowledge, religiosity, attitude and intention. Journal of Islamic Marketing, 6(1), 148-163. https://doi.org/10.1108/JIMA-09-2013-0068

Rao, A. R., \& Monroe, K. B. (1988). The moderating effect of prior knowledge on cue utilization in product evaluations. Journal of consumer research, 15(2), 253-264.

Roscoe, J. T. (1975). Fundamental research statistics for the behavioral sciences [by] John T. Roscoe.

Souiden, N., \& Rani, M. (2015). Consumer attitudes and purchase intentions toward Islamic banks: the influence of religiosity. International Journal of Bank Marketing, 33(2), 143-161. https://doi.org/10.1108/IJBM-10-2013-0115

Tabassi, S. (2012). The role of animosity, religiosity and ethnocentrism on consumer purchase intention: A study in Malaysia toward European brands. African Journal of Business Management, 6(23), 6890-6902.

Teng, P. K., \& Wan Jusoh, W. J. (2013). Investigating student awareness and usage intention towards halal labelled cosmetics and personal care products in Malaysia. In 4th international conference on business and economic research (4th ICBER 2013), Indonesia, Bandung.

Thomson Reuters. (2014), State of the Global Islamic Economy 2014 - 2015 Report. New York: Thomson Reuters

Tsakiridou, E., Mattas, K. Dan Bazoche, P. (2012). Consumers response on the labels of fresh fruits and related implications on pesticide use. Food Economics, 9(1-2) : 129-134. https://doi.org/10.1080/16507541.2012.695113

Yuswohady. (2015). Marketing to the Middle-Class Muslim-Kenali Perubahannya, Pahami Perilakunya, Petakan Strateginya. Jakarta: Penerbit Gramedia Pustaka Utama 